\title{
The Strategic Timing of Direct Democracy
}

\author{
Marc Meredith ${ }^{*}$ \\ Massachusetts Institute of Technology
}

This Version: 10/1/2008

\begin{abstract}
:
This paper focuses on the strategic timing of elections by agenda-setters in direct democracy settings. Because concurrent elections affect turnout, scheduling referenda for different elections will produce different median voters. I hypothesize that agendasetters with power over the timing of a referendum will schedule the referendum in conjunction with the other set of races that produce a policy closest to their preferred outcome. Consistent with the theory, I show that Wisconsin school boards' use of special elections for school referenda are related to differences in the revealed preferences of voters in low and high turnout elections.
\end{abstract}

Key Words: direct democracy, election timing, agenda-setting, school boards

\footnotetext{
* Marc Meredith is a Lecturer, Massachusetts Institute of Technology, Department of Political Science, 77 Massachusetts Avenue, Room E53-470, Cambridge, MA 02139 (mmeredit@mit.edu).

I am grateful to Dan Butler, Silvia Console-Battilana, Jason Grissom, Dan Kessler, Keith Krehbiel, Anna Mastri, Connor Raso, Ken Shotts, and participants at the 2005 Midwest Political Science Association Conference and Stanford's Workshop in Political Statistical Modeling for their helpful comments and suggestions.
} 


\section{Introduction}

Beginning with Romer and Rosenthal's $(1978,1979)$ seminal work, scholars have recognized the importance of agenda-setting in direct democracy. In Romer and Rosenthal's model the agenda-setter derives its power from the ability to select the policy alternatives from which voters choose. However there are a number of cases in the United States in which agenda-setters in direct democracy settings have an additional source of agenda-control: the ability to select the date on which voters choose. In this paper I focus on the ability of agenda-setters in a local public finance and statewide initiative setting to strategically use this election timing power.

The idea that political actors may strategically time elections is not new. In many parliamentary democracies the governing party can call for early elections, which has led to a substantial literature in comparative politics on election timing. ${ }^{1}$ This literature primarily focuses on political actors scheduling elections to take advantage of favorable economic conditions or party valiance. In contrast, the primary source of agenda power in direct democracy is the ability to schedule a referendum concurrently with other races. Because individuals mobilized to vote by other races often cast votes on a referendum, the median voter's preferred policy on a referendum's issue dimension may vary with the remaining composition of the ballot. I hypothesize that agenda-setters with power over the timing of a referendum will schedule the referendum in conjunction with the other set of races that produces a policy closest to their preferred outcome.

To test my theory of the strategic timing of direct democracy I use data on the timing of school referenda in Wisconsin. Wisconsin school boards have the power to

\footnotetext{
${ }^{1}$ See Smith (2004) pp. 22-23 for a summary of this literature.
} 
select the election date for school referenda. I test whether school board's use of special elections for school referenda are related to differences in the support for pro-educational spending political candidates in low and high turnout elections. As predicted by the theory, the use of special elections is related to differences in the revealed preferences of voters in low and high turnout elections. Holding fixed the vote shares of proeducational spending candidates in high turnout elections, school boards are significantly more likely to hold school referenda in special elections as the vote shares of proeducational spending candidates in low turnout elections increases.

Having found evidence that school boards strategically time elections, I next explore whether this strategic timing affects election outcomes. I do so by comparing the passage rates of school referenda by election date in Wisconsin and the neighboring state of Minnesota, where school boards have less agenda-power over the timing of elections. Substantially different patterns are observed in the two states; in Wisconsin the highest passage rate occur in high turnout elections, while in Minnesota the highest passage occurs in low turnout elections. This pattern is suggestive that the strategic timing of elections affects outcomes.

Finally, I discuss the possibility of the strategic timing of statewide initiatives. I specifically focus on the potential for agenda-setters to strategically time initiatives for primary elections. I highlight Proposition 55, an initiative to increase funding for school construction from the 2004 California presidential primary, as an example of an initiative that may have benefited from being held during a primary.

The remainder of the paper proceeds as follows. Section II discusses relevant literature. Section III outlines the school referendum process in Wisconsin, discusses the 
identification strategy to test for strategic timing, and describes the Wisconsin referenda data. Section IV presents results of the tests of strategic timing. Section V discusses the possibility of the strategic timing of statewide initiatives. Section VI concludes.

\section{Relevant Literature}

Romer and Rosenthal's $(1978,1979)$ setter model provides the foundations for this paper. In the setter model a monopolistic budget maximizing agenda-setter leverages the disutility voters receive from the reversion policy if a referendum fails to extract greater expenditure than is preferred by the median voter. The only agenda control available to the setter is the amount of the referendum to be considered against the status quo. In this paper I consider situations where the agenda-setter determines both the alternative and the timing of the election. In such a situation the agenda-setter can also leverage the power to schedule elections to take advantage of any differences in the preferences of voters across different types of elections.

Agenda power over the timing of referenda may be particularly central in a local politics setting because of the importance of election concurrency in affecting voter turnout. The largest determinant of local election participation is the concurrency of a local election with an election for state or federal office (Hajnal and Lewis 2003, Wood 2002). Moreover, differences in turnout propensity in concurrent and stand-alone local elections are thought to be related to outcome preferences. Piele and Hall's (1973) summary of the literature concludes that parents, property owners, and middle-aged voters are relatively more represented in stand-alone school elections than in concurrent elections. More recently Moe (2005) shows that school employees who stand to directly 
benefit from the passage of school referenda vote at disproportionately high rates in special school elections.

Dunne, Reed, and Wilbanks (1997) previously discuss the strategic use of special elections for school referenda. Using a Riker-Ordeshook (1968) turnout framework where individuals vote when their expected benefit from affecting the outcome of the election exceeds the cost of voting, they contend that individuals with extreme preferences are relatively more likely to turnout in stand-alone versus concurrent elections. Arguing that school referenda have concentrated benefits and diffuse costs, Dunne, Reed, and Wilbanks conclude that using special elections increases the probability of passage. Therefore, they contend that use of special elections for referenda is indicative of strategic election timing. Dunne, Reed, and Wilbanks offer three pieces of empirical evidence to support their hypothesis: losing referenda are often proposed again at an equal or greater amount within a relatively short time frame ${ }^{2}$, school bonds are statistically less likely than municipal bonds to be proposed during the time when schools are on summer vacation and school boards elected in non-concurrent elections are more likely to propose school bonds in non-concurrent elections.

This paper advances on Dunne, Reed, and Wilbanks' (1997) analysis. I show that the use of special elections for school referenda is related to differences in the revealed preferences of voters in low and high turnout elections. This provides a more direct and discriminating empirical test of the strategic timing of elections than Dunne, Reed, and

\footnotetext{
${ }^{2}$ See also Romer, Rosenthal, and Ladha (1984) that finds agenda-setters do not completely update on information contained in past election results and Rosenthal (1990) for a discussion on what can and cannot learned from observing a series of proposals.
} 
Wilbanks. ${ }^{3}$ I then use data on repeat referenda to demonstrate that school referenda are not uniformly preferred in stand-alone elections. This finding casts doubt on their conclusion that special elections are always favorable for school referenda and therefore, that special elections are necessarily indicative of election timing. ${ }^{4}$ Finally, I provide some suggestive evidence that election timing may have an important effect on election outcomes.

This paper also complements recent work on spillover effects in direct democracy. A number of recent papers document spillover effects from initiatives onto candidate races and partisan identification (Bowler, Nicholson, and Sequra 2006; Donovan, Tolbert, and Smith 2008; Nicholoson 2005). Indeed, Nicholson argues that political parties strategically use "wedge" initiatives to infuse issues into campaigns. This type of strategic timing of initiatives is done to affect other races concurrently on the ballot. In contrast, I focus on the strategic timing of referenda and initiatives to help the

\footnotetext{
${ }^{3}$ For example, a positive correlation between the use of special elections to elect school board members and special elections to vote on school bonds is likely to exist independent of any strategic behavior due to unobserved community preferences over the number of elections.

${ }^{4}$ This finding is consistent with the mixed empirical evidence on the effects of turnout on support for school referenda. Pecquet, Coats, and Yen (1996) find the proportion supporting Louisiana school bonds is lower in concurrent elections. Rubinfeld (1977) finds that changes in turnout, and not vote choice, explain a shift in the electoral success of a single referendum. Moreover, he finds that these changes in voter turnout are unrelated to changes in the relative price of the referendum caused by a law change. Inman (1978) finds little evidence that voter turnout affects election outcomes in a sample of Long Island, New York school districts. Rubinfeld and Thomas (1980) find no evidence that turnout decisions relate to voter demand for education expenditure in the only micro-level analysis of voter turnout in school referenda.
} 
passage of the referenda and initiatives. The strategic timing of initiatives and referenda for the purpose of passing the referenda and initiative relies on turnout spillovers from other races on the ballot onto initiatives and referenda. Thus while spillovers generate the incentives for strategic timing in both cases, the form of the spillover is quite different.

\section{Wisconsin School District Referenda}

In the early 1990s the state of Wisconsin enacted two laws that reduced school boards' power to increase school spending. The first limited the amount of long-term debt a school district can carry to $10 \%$ of its equalized property value. The second created a revenue limit that capped the amount that a school district can increase its current school expenditure. In both cases the laws allowed for these limits to be exceeded through voter approved referendum. If a referendum passes, school expenditure can increase by the amount specified; a failed referendum implies that school expenditure remains at its current level. ${ }^{5}$ Local school boards determine both the timing and amount of the referendum. If the referendum is held in conjunction with a regularly scheduled election, the school district pays for the ballots and the municipality pays for

\footnotetext{
${ }^{5}$ This implies that the reversion point is the status quo level of funding. Because these referenda are for supplemental funding, there are not the same long-run consequences for failing to pass a referendum as in a state like New York, where failing to pass a referendum may affect the ability to pass future spending as well (Ehrenberg, Ehrenberg, Smith, and Zheng 2004).
} 
the poll workers. If the referendum is scheduled as a special election, the school district is responsible for all costs. ${ }^{6}$

The laws in Wisconsin provide a quasi-experiment to test the theory of the strategic timing of direct democracy. School boards are an agenda-setter that arguably can be characterized as budget maximizers. This characterization may be particularly accurate in this case because referenda only occur when school boards want to increase school spending. Because school boards are responsible for more of the election costs in a special election, all other factors equal, the school board would prefer to hold the referendum as part of a regularly scheduled election. Therefore additional factors must exist to cause school boards to propose referenda in special elections. I predict that an important factor in determining a school board's use of special elections will be differences in the educational spending preferences of likely voters in low and high turnout elections.

To test whether school boards are strategically timing school referenda for elections that turn out voters more favorable to school spending, I need measures of the school expenditure and participation preferences of school districts' electorates. While I am unable to directly observe the expenditure and turnout preferences of school districts' electorates, I do observe the candidate preferences of voters in different types of elections. Because candidate preferences reveal information about school expenditure preferences, differences in school district's revealed candidate preferences in low and high turnout elections provide a proxy of how the school expenditure preferences of

\footnotetext{
${ }^{6}$ The estimated cost of a special election in Appleton, Wisconsin, which had a population of approximately 70,000 in the 2000 Census, is about $\$ 30,000$ (Capital Times, 10/20/2005, A5).
} 
voters differ in regular and special elections. As a result I can test for the strategic use of special elections by examining whether the use of special elections is related to differences in the school districts' revealed candidate preferences in low and high turnout elections.

To give an example of how I use revealed candidate preferences to test for the strategic timing of elections, assume that there exist two candidates, $A$ and $B$, who are known to be supporters of greater school expenditure. Suppose that candidate $A$ runs for office in a high turnout election, while candidate $B$ runs for office in a low turnout election. I define a variable vote differential, which is equal to the percentage of voters in a school district supporting candidate $B$ minus the percentage of voters in a school district supporting candidate $A$. The value of vote differential is taken as a proxy for the differences in the school expenditure preferences of those members of the school district's electorate that turn out to vote in low and high turnout elections. ${ }^{7}$ Because school districts with higher values of vote differential reveal relatively greater support for a pro-educational spending candidate in a low than a high turnout election, I expect that, holding all else equal, vote differential will be positively related to school boards use of special elections for school referenda. ${ }^{8}$

\footnotetext{
${ }^{7}$ Because candidates $A$ and $B$ may differ in valiance, a school district's vote differential only has meaning relative to the vote differential in other school districts.

${ }^{8}$ This identification strategy is similar to Kousser, Lewis, and Masket (2007), which uses differences in Republican gubernatorial candidates' vote shares in California's 2002 general and 2003 recall elections to explain changes in legislators' voting behavior between the 2003 and 2004 legislative sessions.
} 
To implement my identification strategy I need vote shares of pro-educational spending candidates by school district in low and high turnout elections. I use Jim Doyle's two-party vote share in the November 2006 gubernatorial election as my measure of voters' preferences in high turnout elections. Doyle's race against Representative Mark Green was heavily focused on education, with Doyle pledging that the state would fund $2 / 3$ of school costs statewide and Green proposing to freeze school spending and require that 70 percent of all educational spending be mandated for certain classroom expenses. The Wisconsin Education Association Council (WEAC), the state's largest teachers union, campaigned strongly for Doyle. Their president was quoted as saying that "I thing (Mark Green) is clueless about education reform (Wisconsin State Journal, 9/20/2006, D3).” Moreover, WEAC spent more than $\$ 500,000$ on negative ads against Green leading up to the election (The Capital Times, 11/1/2006, A1).

I use Elizabeth Burmaster's vote share in the April 2005 Wisconsin State Superintendent of Education election as my measures of voters' preferences in low turnout elections. The Wisconsin State Superintendent of Education race has a number of appealing characteristics that make it a good election from which to proxy the behavior of voters in a special school referendum election. First, the primary campaign issue was the funding of public schools with Burmaster favoring greater education spending and her opponent Gregg Underheim supporting spending freezes (Wisconsin State Journal, $4 / 2 / 2005, \mathrm{C} 1){ }^{9}$ Second, because the race is statewide, a common measure for

\footnotetext{
${ }^{9}$ Burmaster's campaign focused on the issue of increasing the state's share of educational funding. Underheim, in contrast, campaigned for greater spending controls and a property-tax freeze (Wisconsin State Journal, 4/2/2005, C1). This lead the WEAC to spend more money than both of the candidates
} 
expenditure preferences can be generated across all school districts. Third, the superintendents' race was the only contested statewide race on the ballot. As a result, voters in this election are likely to be similar to those voters who are motivated to vote in a special school referendum election. ${ }^{10}$

I construct measures of Doyle's and Burmaster's vote shares by school district using ward level election returns from the Wisconsin State Elections Board. Ward level election returns are allocated to school districts using a correspondence between wards and school districts from the Missouri Census Data Center. In the case where multiple school districts are contained within a single ward, votes are allocated to school districts by the proportion of the wards' population that lives in each school district. I also construct vote shares for a number of additional electoral races by school district, including John Kerry two-party vote share in the 2004 presidential election, Jim Doyle's two-party vote share in the 2002 election, Elizabeth Burmaster's vote share in the 2001 state superintendent election, and Al Gore's two-party vote share in the 2000 presidential election.

combined in their independent expenditures supporting Burmaster (Wisconsin State Journal, 3/30/2005, B3).

${ }^{10}$ Ideally, I also would be able to test how the ability to time referenda affects the amount proposed. Unfortunately, I cannot estimate the counterfacutual spending assuming no ability to strategically time using only Wisconsin data because there is no variation within Wisconsin in school boards' ability to strategically time. Moreover, because my electoral preferences used to construct the vote differential are Wisconsin specific, I cannot use data from outside of Wisconsin to construct the counterfactual because I don't have a measure of the incentive to strategically time across districts. Therefore, I am unable to estimate the effect of strategic timing on referenda proposals. 
Data on school referenda are downloaded from the Wisconsin Department of Public Instruction. I construct a dataset of all Wisconsin school referenda from 1990 2006. These data include information on the dates of election, the amount of the referendum, votes in favor of the referendum, votes against the referendum, the type of referendum, school year(s) for which the referendum applies, and a brief verbal description of the specific purpose of the referendum. A total of 2099 separate referenda occurred between 1990 - 2006. After combining referenda occurring on the same day, I am left with a final sample of 1482 observations, which implies the average number of referendum elections per school district from 1990 to 2006 is about 3.5. I classify referendum as being for one of three different types of expenditures: debt, reoccurring costs, or nonrecurring costs. Debt referenda are generally for the construction of new facilities or major capital improvements like auditoriums or athletic facilities. Reoccurring cost referenda are for permanent increases in the reversion point and are typically used for general operating expenses. Non-reoccurring cost referenda are for short-term increases in the reversion point and are typically for maintenance or technological improvements. I calculate the real present value of all referendum at the time of election. ${ }^{11}$ I assume that expenditures on debt referenda occur immediately and expenditures on non-debt referendum occur on September $1^{\text {st }}$ of their listed starting year. ${ }^{12}$

\footnotetext{
${ }^{11}$ The results in this paper assume a continuously compounded social discount rate of $5 \%$. Changing this assumption has no substantive effect on the results.

${ }^{12}$ Exceptions to this rule are referenda that were voted on after September $1^{\text {st }}$ of the listed starting year, which are assumed to start on the election date. If no start year is provided, expenditures are assumed to occur on the September $1^{\text {st }}$ following the election.
} 
To determine whether an election is a regular or special election, dates of primary and general statewide elections are obtained from volumes of the Wisconsin Blue Book. An election is classified as being a special election if it occurred on a day in which a primary or general statewide election did not occur. Every year a statewide election occurs the third Tuesday in February and the first Tuesday in April. ${ }^{13}$ State law requires all city, village, town, and school board elections to occur in conjunction with this April statewide election. In even years there are additional statewide elections the third Tuesday in September and the first or second Tuesday in November.

Additional control variables are defined using 2000 Census data allocated to school districts by the National Center for Education Statistics. This provides information on population by age group, the number and types of households with children, percent of individuals age 25 and older obtaining certain levels of education, percent of structures occupied by owners, median household income, population by racial group, and percent of population living in a rural area. This data is supplemented with data from the Wisconsin Department of Public Instruction on the percentage of students enrolled in public schools in the school district in 2000. I approximate the percentage of the electorate with children enrolled in the public schools by multiplying the percentage of adults with children in the district by the percentage of students in the district attending public school. Descriptive statistics for all of the variables is contained in Table 1.

\footnotetext{
${ }^{13}$ The one exception is 1996, when the elections were moved up two weeks to accommodate the Wisconsin presidential primary.
} 


\section{Analysis}

I model the decision to hold a special election using a probit regression specification where school boards in district $i$ propose a referendum in a special election at time $t$ when $V_{i t}>0$,

$$
V_{i t}=\alpha+\lambda\left(\% \text { Burmaster }_{i}\right)+\delta\left(\% \text { Doyle }_{i}\right)+\theta X_{i t}+\varepsilon_{i t}
$$

where $V_{\text {it }}$ is modeled as a function of Elizabeth Burmaster's vote share in the 2005 state superintendent race, \% Burmaster $;$; Jim Doyle's vote share in the 2006 governor race, $\%$ Doyle $i$; a vector of covariates including: the percentage of the electorate over the age 65 , the percentage of electorate with children in public school, the percentage of owner occupied properties, the percentage of the population rural, the percentage of the population that is non-white, the log of the median household income, the percentage of the population over 25 with a high school diploma, and the percentage of the population over 25 with a college degree, the logged size of the electorate, the real present value of the referendum, and dummy variables for the type referendum, $\mathrm{X}_{\mathrm{it}}$; and an error term ! it which is assumed to be distributed $N\left(0, \sigma_{i}^{2}\right)$ and clustered by school district to control for any school district specific heterogeneity.

The primary coefficient of interest in equation (1) is $\lambda$, which provides an estimate of how an increase in Elizabeth Burmaster's vote share affects the use of special elections holding fixed Jim Doyle's vote share. I use this specification rather than just including the differential in Burmaster's and Doyle's vote share (\% Burmaster - \% Doyle) to control for any effect of the general liberalness of a school district in holding special elections. I could alternatively use the Burmaster and Doyle vote differential and Doyle's vote share as the two primary explanatory variables. In such a specification the 
coefficient on the vote differential would be the same as $\lambda$ from (1), though it would change the value and interpretation of the coefficient on Doyle's vote share.

As discussed in the previous section, fewer statewide elections occur in odd years. Consequently a larger percentage of referenda are held in special elections in odd years $(57.7 \%)$ than even years $(28.8 \%)$. By not controlling for this effect, the estimated coefficients may suffer from omitted variable bias. Because the scheduling of an election for this period is strategic choice, however, including an odd year dummy variable could potentially bias the coefficients. As a result I estimate regression specifications twice: once with and once without an odd year dummy variable. Obtaining similar coefficient estimates in both specifications helps alleviate bias concerns.

Regression results are presented in Table 2. The regression reported in column (1) uses the full sample of referenda from 1990 - 2006 and includes the percent Burmaster, the percent Doyle the percent of electorate with children in public schools, the percent of the electorate over 65 , and indicators for the type of referenda as covariates. Using this specification I estimate that $\lambda=0.017(p=0.031)$. This estimate of $\lambda$ implies that holding all other covariates at their sample average, a one standard deviation increase in vote differential increases the probability of holding a special election by 4.8 percentage points. I obtain almost an identical estimate of $\lambda$ in the regression reported in column (2) that adds an odd year dummy variable. In the regressions reported in columns (3) and (4) I also include a number of additional control variables. Using the full specification in column (4), I estimate that $\lambda=0.017(p=0.034)$, which corresponds to a 4.7 percentage point increase in the probability of holding a special election from a one 
standard deviation increase in vote differential when holding other variables at their sample means.

I present a number of robustness checks on my baseline specification in columns $(5)-(8)$ of Table 2. One weakness of the baseline regressions reported in columns (1)(4) of Table 2 is that I use election results from 2005 and 2006 to proxy for characteristics of school districts' electorates going back to 1990. Because characteristics of the electorate change over time, these election results are likely to be a better proxy for preference in later part of my sample. As a result, I also estimate all of my specifications using only those referenda held between 2000 and 2006. In column (5) I report the results using the 2000 to 2006 restricted sample that are analogous to the full specification reported in column (4). In this sample I find a somewhat larger point estimate of $\lambda=0.019(p=0.103)$, albeit with a slightly larger standard error. I continue to find results similar to the baseline in column (6) when I exclude referenda held on the day of the 2005 state superintendent election and 2006 governor election. In additional unreported regressions I also change the definition of a special election to be all those elections that were not scheduled in conjunction with a general election or a presidential primary and continue to find a positive significant effect of Burmaster's 2005 vote share on the use of these elections.

I test how candidate vote shares from a number of additional races correlate with the use of special elections in columns (7) and (8) of Table 2. I replace Jim Doyle's twoparty vote share in 2006 gubernatorial election with the average of Al Gore's vote share in the 2000 presidential election, Jim Doyle's vote share in the 2002 gubernatorial election, John Kerry's vote share in the 2004 presidential election, and Jim Doyle's vote 
share in the 2006 gubernatorial election in the regression reported in column (7). I estimate $\lambda=0.017(p=0.035)$ in the specification, which implies that a one-standard deviation in the differential of Burmaster's vote share in 2005 and the average vote share of the Democratic candidates across the four elections increase the use of special elections by 4.7 percentage points. I replace Burmaster's vote share in 2005 with her vote share in the 2001 election in column (8). I find no significant effect of Burmaster's vote share in 2001 on the use of special elections. ${ }^{14}$ Unfortunately, I cannot investigate the effects of vote shares for state superintendent candidates prior to 2001 , because precinct-level results are unavailable.

Two additional patterns emerge from the results reported in Table 2. The first is that more expensive referenda are more likely to be held in special elections. There are multiple potential mechanisms for this result. First, the fixed cost of holding a special election may make them prohibitively costly for small referenda. Instead, school boards may be endogenously raising the referenda amount in special elections. Finally, it may be that expensive referenda perform relatively worse in high turnout elections. The second pattern of note is that non-reoccurring cost referenda are less likely to be held in special elections. As previously mentioned, non-reoccurring referenda tend to be for expenditures on maintenance or technological improvements. Previous research has suggested that in the cross-section such expenditures are more popular with the electorate at-large (Beckman and Maiden, 2003). As a result, such referenda may perform

\footnotetext{
${ }^{14}$ One possible explanation for this finding is that Burmaster was not viewed as favorably by supporters of high education spending in the 2001 election. While teachers unions backed Burmaster in the 2001 general election, this was after many unions endorsed her opponents in the primary.
} 
relatively better among the types of voters who are induced to vote by the other races on the ballot.

While the results in Table 2 suggest that school boards strategically time elections, there is still a question of whether the ability to strategically time elections allows school districts to gain favorable outcomes. To gain some insight into this question I compare outcomes of school referenda in Wisconsin the neighboring state of Minnesota. Minnesota school boards are required to hold school referenda on the first Tuesday following November $1^{\text {st }}$. This gives Minnesota school boards much less power to strategically time elections than their Wisconsin counterparts. As a result, I use Minnesota passages rates as an approximate benchmark if strategic timing was not available.

Table 3 compares the passage rates of school referenda by election type in Wisconsin and Minnesota. Table 3 shows a stark contrast between Wisconsin and Minnesota in the relationship between the passage rates of school referenda with election type. Consistent with the theory of Dunne, Reed, and Wilbanks (1997), school referenda pass at a much higher rate in Minnesota in odd (73.82\%) than in even (54.35\%) years (when school referenda are paired with federal elections). In Wisconsin the opposite pattern is observed; referenda proposed in November general elections have a higher probability of passage than referenda proposed in any other kind of election. This occurs even though Table 4 shows that general election voters in the two states are very similar demographically. This finding further suggests that Wisconsin school boards are aware of the characteristics of their school district's electorate and schedule referenda accordingly. Moreover, it suggests that while Dunne, Reed, Wilbanks are correct that on 
average school referenda will perform better in lower turnout elections, this is not universally true across school districts.

To better understand the mechanisms leading to the patterns observed in Table 3 , I would like to compare the characteristics of Wisconsin and Minnesota voters in high and low turnout elections. Unfortunately, neither a centralized voter file nor 2005 exit poll data are available for Wisconsin. As a second-best solution, I compare characteristics of Minnesota school referenda voters in even and odds years using the Minnesota Statewide Voter File. The Minnesota Statewide Voter File contains the name, address, age, and voting history for all registered voters in Minnesota. ${ }^{15}$ I use this data to construct the percentage of voter by age cohort in 29 school districts that held referenda in 2004 and in either 2003 or 2005.

Table 5 shows in all 29 elections that voters in the off-cycle elections are older than voters in the on-cycle election. On average there is a 9 percentage point reduction in the percentage of voters who are age $18-30$, which is compensated by a 7 percentage point increase in the percentage of voters age 55 and older. This suggests that the turnout decisions of older voters are more inelastic with respect to electoral environment than younger voters. This increased proportion of older voters in low turnout elections may help to offset any increase in the proportion of high demanders, which could explain the mixed findings in past literature about the relationship between turnout and school referenda outcomes. Moreover, Table 5 indicates there is heterogeneity across school

\footnotetext{
${ }^{15}$ Unfortunately, a number of variables of interest that are found in some other states' voter files, such as race, gender, or political affiliation, are not contained in the Minnesota file.
} 
districts in the relative increase in elderly voters in low turnout elections, consistent with the finding that there are differential incentives to use low turnout elections.

\section{Statewide Initiatives}

Empirical evidence in the previous section suggests that agenda-setters in a local public finance setting strategically time referenda. In this section I consider whether agenda-setters may also be able to do the same in the statewide initiative context. There is heterogeneity in the agenda rules specifying the types of elections in which statewide initiatives reach voters. A majority of initiative states restrict initiatives to general election ballots. In Alaska, California, North Dakota, and Oklahoma statewide initiatives are allowed on primary or special election ballots, while in Colorado, Maine, Mississippi, Ohio, and Washington initiatives are allowed in odd year statewide elections (Waters, 2003). Those voters who abstain in primary, special, and odd-year elections are generally not randomly selected from the population of general election voters. As a result, there may be situations where agenda-setters strategically schedule their initiatives for these elections. $^{16}$

Primary elections may be particularly ripe for the strategic timing of initiatives because it is often well known in advance that one party will be mobilized disproportionately. Because first-term presidents often run unopposed for their parties' nomination in the next election cycle, agenda-setters often can anticipate which parties electorate will be mobilized to participate more in presidential primary elections. For

\footnotetext{
${ }^{16}$ For example, Hasen (2007) discusses the potential for the strategic timing of initiatives regarding Electoral College apportionment.
} 
example, leading up the 2004 presidential primaries, initiative agenda-setters could predict that the contested Democratic presidential primaries would be more competitive than their uncontested Republican counterparts. As a result, these agenda-setters could expect that voters in the 2004 primary elections would be more liberal than voters in the 2004 general election.

California Proposition 55 provides an example of how the strategic timing of initiatives could affect election outcomes. Proposition 55, a twelve billion dollar bond issue for school construction and repair, passed by 51 percent to 49 percent margin in the 2004 presidential primary. According to an LA Time exit poll, 63 percent of Democratic identifiers and 65 percent of liberal identifiers supported Proposition 55 compared to 34 percent of both Republican and conservative identifiers. Given Proposition 55's narrow victory and Democratic support, it seems fortuitous to supporters of Proposition 55 that only Democratic voters were mobilized by a contested presidential primary. Table 6 demonstrates that 2004 primary voters were in fact more liberal and Democratic identifying than 2004 general election voters. This is in contrast to the 2000 California presidential primary, which saw more Republican and conservative voters participate in the primary than the general election. Thus, it is certainly plausible that foreseen differences in the subset of the electorate that voted in 2004 primary and general elections could have affected the outcome of Proposition 55.

\section{Conclusion}

Direct democracy is often justified normatively on the grounds that it represents the will of the median voter. This justification is less compelling if agenda-setters are 
selecting the median voter. This paper demonstrates that agenda-setters can use election timing power to select voters that will be more favorable towards their policy interests. As a result, both researchers and policy makers need to seriously consider how the rules surrounding agenda establishment in direct democracy affect economic and political outcomes.

The policy question of whether initiatives and referenda should be allowed in offcycle elections is closely related to a similar question of whether local elections should be scheduled concurrently with state and federal elections. Hajnal and Lewis (2003) document the substantial increase in turnout in local elections when local elections are paired with state and federal elections. At the same time they also note that historically there have been a number of objections to pairing local elections with higher turnout state and federal elections. One objection is that information needed to make informed choices may be crowded out by coverage of higher profile races. Another objection is that voters with limited knowledge of issues at hand may feel obligated to cast ballots. ${ }^{17}$ These objections are particularly relevant to initiatives and referenda because uninformed voters tend to systematically choose the status quo policy (Christin, Hug, and Sciarini 2002).

In 2005, the Wisconsin State Senate considered Senate Bill 171, which would have limited the power of school boards to use special elections. While it did not ultimately pass, this demonstrates that policy-makers are concerned about the potential for strategic timing. As legislators consider laws like that proposed in Wisconsin to limit the agenda-setting power of schools boards, the fundamental question that is yet

\footnotetext{
${ }^{17}$ For example, Meredith and Salant (2008) show that ballot-order effects affect the outcome of local elections more when the elections are concurrent with federal elections.
} 
unanswered is whether there exist circumstances where voters would select different policies in different electoral environments, independent of any changes in voter turnout. This may occur, for example, if increased information about initiatives and referenda were available in periods without high salient candidate races. If such situations exist, then the ability for an agenda-setter to endogenously time elections could potentially be welfare improving for the median voter. If not, these rules would seem to directly benefit agenda-setters at the expense of the median voter. 
Table 1

Descriptive Statistics (N=1482)

\begin{tabular}{|c|c|c|c|c|}
\hline Variable & Mean & Std. Dev. & Min & Max \\
\hline Special Election Dummy & 0.41 & 0.50 & 0 & 1 \\
\hline Burmaster vote share in '05 State Superintendent Election & 61.20 & 6.05 & 38.92 & 78.17 \\
\hline Doyle two-party vote share in '06 Gubernatorial Election & 50.52 & 9.73 & 22.96 & 83.11 \\
\hline Kerry two-party vote share in '04 Presidential Election & 45.86 & 9.61 & 20.88 & 83.06 \\
\hline Doyle two-party vote share in '02 Gubernatorial Election & 48.84 & 10.23 & 22.36 & 79.93 \\
\hline Burmaster vote share in '01 State Superintendent Election & 58.28 & 6.65 & 38.55 & 78.40 \\
\hline Gore two-party vote share in '00 Presidential Election & 46.21 & 9.18 & 21.20 & 80.83 \\
\hline$\%$ Electorate $65+$ & 18.52 & 5.05 & 5.19 & 34.20 \\
\hline$\%$ Electorate w/ Child in Public Schools & 28.60 & 5.27 & 13.02 & 43.98 \\
\hline Debt Referendum Dummy & 0.72 & 0.45 & 0 & \\
\hline Nonrecurring Referendum Dummy & 0.14 & 0.34 & 0 & \\
\hline Odd Year Dummy & 0.44 & 0.50 & 0 & \\
\hline Log (Real Referendum Amount / Electorate) & 6.22 & 1.22 & 1.63 & 9.39 \\
\hline Percent of Property Owner Occupied & 77.60 & 7.73 & 45.31 & 97.06 \\
\hline Percent of Population Rural & 63.23 & 37.21 & 0 & 100 \\
\hline Percent of Population Non-White & 4.54 & 6.25 & 0 & 87.84 \\
\hline Log (Median Household Income) & 10.71 & 0.23 & 10.17 & 11.51 \\
\hline Percent of Pop. 25+ w/ High School Diploma & 85.50 & 4.95 & 70.10 & 97.98 \\
\hline Percent of Pop. $25+w /$ College Degree & 18.91 & 9.26 & 6.23 & 70.92 \\
\hline Log (Electorate) & 8.69 & 1.03 & 5.75 & 12.96 \\
\hline
\end{tabular}


Table 2

Probit Regression on an Indicator for a Special Election

Robust Errors Clustered By School District

\begin{tabular}{|c|c|c|c|c|c|c|c|c|}
\hline $\begin{array}{l}\text { Included Years } \\
\text { Number of Observations } \\
\text { McFadden's R Squared } \\
\% \text { Correctly Classified }\end{array}$ & $\begin{array}{c}(1) \\
90-06 \\
1482 \\
0.018 \\
59.0 \\
\end{array}$ & $\begin{array}{c}(2) \\
90-06 \\
1482 \\
0.073 \\
66.1 \\
\end{array}$ & $\begin{array}{c}(3) \\
90-06 \\
1482 \\
0.027 \\
59.3 \\
\end{array}$ & $\begin{array}{c}(4) \\
90-06 \\
1482 \\
0.083 \\
65.7 \\
\end{array}$ & $\begin{array}{c}(5) \\
00-06 \\
604 \\
0.097 \\
75.5 \\
\end{array}$ & $\begin{array}{c}(6) \\
90-96 \\
1420 \\
0.087 \\
66.1 \\
\end{array}$ & $\begin{array}{c}(7) \\
90-06 \\
1482 \\
0.083 \\
65.7 \\
\end{array}$ & $\begin{array}{c}(8) \\
90-06 \\
1482 \\
0.081 \\
65.9 \\
\end{array}$ \\
\hline Constant & $\begin{array}{c}-1.736 \\
(0.491)\end{array}$ & $\begin{array}{l}-2.023 \\
(0.492)\end{array}$ & $\begin{array}{c}0.792 \\
(4.273)\end{array}$ & $\begin{array}{c}1.084 \\
(4.154)\end{array}$ & $\begin{array}{c}3.251 \\
(5.317)\end{array}$ & $\begin{array}{c}0.677 \\
(4.264)\end{array}$ & $\begin{array}{c}1.130 \\
(4.110)\end{array}$ & $\begin{array}{c}3.765 \\
(4.230)\end{array}$ \\
\hline$\%$ Burmaster '05 & $\begin{array}{c}0.017 \\
(0.008)\end{array}$ & $\begin{array}{c}0.016 \\
(0.008)\end{array}$ & $\begin{array}{c}0.017 \\
(0.008)\end{array}$ & $\begin{array}{c}0.017 \\
(0.008)\end{array}$ & $\begin{array}{c}0.019 \\
(0.012)\end{array}$ & $\begin{array}{c}0.015 \\
(0.008)\end{array}$ & $\begin{array}{c}0.017 \\
(0.008)\end{array}$ & \\
\hline$\%$ Burmaster '01 & & & & & & & & $\begin{array}{c}-0.004 \\
(0.009)\end{array}$ \\
\hline$\%$ Doyle '06 & $\begin{array}{c}0.005 \\
(0.005)\end{array}$ & $\begin{array}{c}0.004 \\
(0.005)\end{array}$ & $\begin{array}{c}0.003 \\
(0.005)\end{array}$ & $\begin{array}{c}0.001 \\
(0.006)\end{array}$ & $\begin{array}{c}0.010 \\
(0.009)\end{array}$ & $\begin{array}{c}0.002 \\
(0.006)\end{array}$ & & \\
\hline (\% Gore '00 + \% Doyle '02 + \% Kerry '04 + \% Doyle '06) / & & & & & & & $\begin{array}{c}0.001 \\
(0.006)\end{array}$ & $\begin{array}{c}0.009 \\
(0.007)\end{array}$ \\
\hline$\%$ of Electorate $65+$ & $\begin{array}{c}0.004 \\
(0.010)\end{array}$ & $\begin{array}{c}0.006 \\
(0.010)\end{array}$ & $\begin{array}{l}-0.009 \\
(0.015)\end{array}$ & $\begin{array}{l}-0.010 \\
(0.014)\end{array}$ & $\begin{array}{c}-0.028 \\
(0.019)\end{array}$ & $\begin{array}{c}-0.012 \\
(0.015)\end{array}$ & $\begin{array}{l}-0.010 \\
(0.014)\end{array}$ & $\begin{array}{c}-0.011 \\
(0.014)\end{array}$ \\
\hline Debt & $\begin{array}{c}-0.068 \\
(0.094)\end{array}$ & $\begin{array}{c}-0.081 \\
(0.094)\end{array}$ & $\begin{array}{c}-0.103 \\
(0.096)\end{array}$ & $\begin{array}{c}-0.106 \\
(0.097)\end{array}$ & $\begin{array}{c}-0.111 \\
(0.161)\end{array}$ & $\begin{array}{c}-0.144 \\
(0.098)\end{array}$ & $\begin{array}{c}-0.106 \\
(0.097)\end{array}$ & $\begin{array}{c}-0.108 \\
(0.097)\end{array}$ \\
\hline Non-reoccurring Cost Referendum & $\begin{array}{c}-0.493 \\
(0.134)\end{array}$ & $\begin{array}{l}-0.522 \\
(0.135)\end{array}$ & $\begin{array}{l}-0.428 \\
(0.141)\end{array}$ & $\begin{array}{l}-0.470 \\
(0.142)\end{array}$ & $\begin{array}{l}-0.069 \\
(0.199)\end{array}$ & $\begin{array}{l}-0.395 \\
(0.149)\end{array}$ & $\begin{array}{l}-0.469 \\
(0.142)\end{array}$ & $\begin{array}{c}-0.469 \\
(0.143)\end{array}$ \\
\hline Odd Year & & $\begin{array}{c}0.710 \\
(0.062)\end{array}$ & & $\begin{array}{c}0.718 \\
(0.063)\end{array}$ & $\begin{array}{c}0.779 \\
(0.110)\end{array}$ & $\begin{array}{c}0.760 \\
(0.065)\end{array}$ & $\begin{array}{c}0.718 \\
(0.063)\end{array}$ & $\begin{array}{c}0.718 \\
(0.063)\end{array}$ \\
\hline Log (Real Referendum Amount / Electorate) & & & $\begin{array}{c}0.090 \\
(0.032)\end{array}$ & $\begin{array}{c}0.080 \\
(0.034)\end{array}$ & $\begin{array}{c}0.071 \\
(0.066)\end{array}$ & $\begin{array}{c}0.095 \\
(0.034)\end{array}$ & $\begin{array}{c}0.080 \\
(0.034)\end{array}$ & $\begin{array}{c}0.074 \\
(0.033)\end{array}$ \\
\hline$\%$ Property Owner Occupied & & & $\begin{array}{c}0.002 \\
(0.008)\end{array}$ & $\begin{array}{c}0.002 \\
(0.008)\end{array}$ & $\begin{array}{c}0.019 \\
(0.013)\end{array}$ & $\begin{array}{c}0.001 \\
(0.008)\end{array}$ & $\begin{array}{c}0.002 \\
(0.008)\end{array}$ & $\begin{array}{c}0.003 \\
(0.008)\end{array}$ \\
\hline$\%$ of Population Rural & & & $\begin{array}{c}0.002 \\
(0.002)\end{array}$ & $\begin{array}{c}0.003 \\
(0.002)\end{array}$ & $\begin{array}{c}0.001 \\
(0.003)\end{array}$ & $\begin{array}{c}0.003 \\
(0.002)\end{array}$ & $\begin{array}{c}0.003 \\
(0.002)\end{array}$ & $\begin{array}{c}0.002 \\
(0.002)\end{array}$ \\
\hline
\end{tabular}




\begin{tabular}{|c|c|c|c|c|c|c|}
\hline $\begin{array}{l}\% \text { of Population Non-White } \\
\text { Log (Median Household Income) } \\
\% \text { of Pop. } 25+\text { w/ High School Diploma } \\
\% \text { of Pop. } 25+\text { w/ College Degree } \\
\text { Log (Electorate) }\end{array}$ & $\begin{array}{c}-0.350 \\
(0.407) \\
0.008 \\
(0.007) \\
0.010 \\
(0.015) \\
0.004 \\
(0.008) \\
-0.005 \\
(0.054)\end{array}$ & $\begin{array}{c}-0.355 \\
(0.397) \\
0.008 \\
(0.007) \\
0.006 \\
(0.015) \\
0.006 \\
(0.008) \\
-0.010 \\
(0.054)\end{array}$ & $\begin{array}{c}-0.821 \\
(0.535) \\
-0.006 \\
(0.015) \\
0.005 \\
(0.022) \\
0.013 \\
(0.013) \\
0.101 \\
(0.079)\end{array}$ & $\begin{array}{c}-0.343 \\
(0.404) \\
0.007 \\
(0.007) \\
0.010 \\
(0.015) \\
0.004 \\
(0.008) \\
0.002 \\
(0.056)\end{array}$ & $\begin{array}{c}-0.359 \\
(0.393) \\
0.008 \\
(0.007) \\
0.006 \\
(0.015) \\
0.006 \\
(0.008) \\
-0.010 \\
(0.055)\end{array}$ & $\begin{array}{c}-0.513 \\
(0.402) \\
0.008 \\
(0.007) \\
0.006 \\
(0.015) \\
0.007 \\
(0.008) \\
-0.026 \\
(0.054)\end{array}$ \\
\hline
\end{tabular}


Table 3

Comparing Election Outcomes by Date of Election for Referenda from 1990 - 2006

\begin{tabular}{|rr|r|r|r|r|}
\cline { 3 - 5 } \multicolumn{1}{l|}{ Wisconsin } & N & Passed & Mixed & Rejected \\
& November On-Cycle & 184 & $59.78 \%$ & $7.07 \%$ & $33.15 \%$ \\
& Federal Primaries & 193 & $52.85 \%$ & $7.77 \%$ & $39.38 \%$ \\
& February Statewide Elections & 139 & $46.04 \%$ & $6.47 \%$ & $47.48 \%$ \\
& April Statewide Elections & 340 & $45.00 \%$ & $8.53 \%$ & $46.47 \%$ \\
Minnesota & Special Elections & 580 & $50.00 \%$ & $5.87 \%$ & $44.13 \%$ \\
& & & & \\
& November On-Cycle & 537 & $54.38 \%$ & $2.05 \%$ & $43.58 \%$ \\
& November Off-Cycle & 699 & $73.82 \%$ & $1.29 \%$ & $24.89 \%$ \\
\hline
\end{tabular}


Table 4

Characteristics of Minnesota and Wisconsin Voters in 2006 General Election

\begin{tabular}{|l|c|c|}
\cline { 2 - 3 } \multicolumn{1}{c|}{} & MN & WI \\
Female & $51.1 \%$ & $52.5 \%$ \\
White & $90.3 \%$ & $90.7 \%$ \\
Age $18-29$ & $15.5 \%$ & $17.3 \%$ \\
Age $30-49$ & $36.7 \%$ & $32.5 \%$ \\
Age $40-64$ & $30.6 \%$ & $29.1 \%$ \\
Age 65+ & $16.9 \%$ & $20.5 \%$ \\
Democrats & $37.9 \%$ & $35.7 \%$ \\
Republicans & $33.6 \%$ & $32.0 \%$ \\
Earning Above 50k & $56.5 \%$ & $52.9 \%$ \\
Earning Above 100k & $19.5 \%$ & $14.6 \%$ \\
College Educated & $42.1 \%$ & $34.9 \%$ \\
\hline
\end{tabular}

Source: National Election Pool Exit Polls 
Table 5 - Characteristics of Minnesota School Referenda Voters in Odd and Even Years

\begin{tabular}{|c|c|c|c|c|c|c|c|c|c|}
\hline \multirow[b]{3}{*}{ School District } & \multicolumn{3}{|c|}{$\%$ of Votes Age $18-30$} & \multicolumn{3}{|c|}{$\%$ of Voters Age $55+$} & \multicolumn{3}{|c|}{ Number of Participants } \\
\hline & (1) & (2) & (3) & (4) & (5) & (6) & (7) & (8) & (9) \\
\hline & '03 or '05 & '04 & Difference & '03 or '05 & '04 & Difference & '03 or '05 & '04 & Ratio \\
\hline CENTENNIAL & 7.08 & 18.24 & -11.16 & 22.15 & 18.00 & 4.15 & 7,879 & 16,281 & 0.484 \\
\hline COLUMBIA HEIGHTS & 8.31 & 18.11 & -9.80 & 53.34 & 39.30 & 14.04 & 4,288 & 11,408 & 0.376 \\
\hline FRAZEE & 9.30 & 16.57 & -7.27 & 46.72 & 38.73 & 7.99 & 1,734 & 3,447 & 0.503 \\
\hline WACONIA & 7.44 & 18.93 & -11.49 & 32.57 & 23.70 & 8.87 & 2,860 & 8,257 & 0.346 \\
\hline NORTH BRANCH & 9.06 & 19.54 & -10.48 & 14.82 & 10.61 & 4.21 & 4,201 & 9,939 & 0.423 \\
\hline KASSON-MANTORVILLE & 6.37 & 18.25 & -11.88 & 31.08 & 23.42 & 7.66 & 1,448 & 4,723 & 0.307 \\
\hline ORONO & 4.65 & 13.02 & -8.37 & 34.02 & 26.59 & 7.43 & 3,731 & 7,436 & 0.502 \\
\hline PARK RAPIDS & 6.41 & 13.02 & -6.61 & 55.34 & 48.10 & 7.24 & 3,669 & 6,690 & 0.548 \\
\hline PRINCETON & 8.35 & 19.70 & -11.35 & 39.12 & 27.57 & 11.55 & 3,274 & 9,950 & 0.329 \\
\hline ROYALTON & 10.11 & 18.31 & -8.20 & 39.42 & 30.81 & 8.61 & 962 & 1,782 & 0.540 \\
\hline STEWARTVILLE & 6.70 & 18.97 & -12.27 & 44.36 & 31.15 & 13.21 & 1,394 & 4,171 & 0.334 \\
\hline OKLEE & 15.53 & 17.18 & -1.65 & 40.15 & 39.69 & 0.46 & 313 & 645 & 0.485 \\
\hline ELK RIVER & 7.61 & 20.47 & -12.86 & 26.03 & 20.39 & 5.64 & 9,443 & 28,968 & 0.326 \\
\hline HOLDINGFORD & 8.09 & 17.87 & -9.78 & 40.72 & 31.04 & 9.68 & 1,031 & 2,481 & 0.416 \\
\hline KIMBALL & 11.88 & 19.27 & -7.39 & 38.28 & 31.59 & 6.69 & 1,226 & 2,426 & 0.505 \\
\hline ROCORI & 5.12 & 15.98 & -10.86 & 44.04 & 33.65 & 10.39 & 2,975 & 6,979 & 0.426 \\
\hline SEBEKA & 8.18 & 15.01 & -6.83 & 49.23 & 41.39 & 7.84 & 659 & 1,640 & 0.402 \\
\hline WINONA AREA & 18.28 & 33.03 & -14.75 & 38.82 & 29.33 & 9.49 & 12,343 & 18,779 & 0.657 \\
\hline ROCKFORD & 7.80 & 19.47 & -11.67 & 28.24 & 21.61 & 6.63 & 2,271 & 4,993 & 0.455 \\
\hline ST. MICHAEL-ALBE & 9.82 & 23.23 & -13.41 & 23.34 & 16.73 & 6.61 & 2,941 & 10,082 & 0.292 \\
\hline MAPLE RIVER & 7.68 & 18.40 & -10.72 & 44.79 & 34.90 & 9.89 & 941 & 3,406 & 0.276 \\
\hline MINNEWASKA & 8.75 & 17.30 & -8.55 & 46.46 & 41.87 & 4.59 & 2,827 & 5,358 & 0.528 \\
\hline LUVERNE & 9.25 & 14.95 & -5.70 & 49.24 & 44.48 & 4.76 & 2,044 & 3,636 & 0.562 \\
\hline CLEARBROOK-GONVICK & 8.50 & 14.07 & -5.57 & 52.51 & 46.83 & 5.68 & 916 & 1,544 & 0.593 \\
\hline NORMAN COUNTY WEST & 8.88 & 14.10 & -5.22 & 45.75 & 41.47 & 4.28 & 510 & 849 & 0.601 \\
\hline HOWARD LAKE-WAVERLY-WINSTED & 12.31 & 20.23 & -7.92 & 36.04 & 30.44 & 5.60 & 3,318 & 4,368 & 0.760 \\
\hline EAGLE VALLEY & 5.13 & 15.49 & -10.36 & 50.83 & 44.57 & 6.26 & 519 & 1,392 & 0.373 \\
\hline LAKE PARK-AUDUBON & 5.83 & 14.06 & -8.23 & 50.28 & 42.90 & 7.38 & 1,114 & 2,672 & 0.417 \\
\hline REDWOOD FALLS AREA SCHOOLS & 10.47 & 15.86 & -5.39 & 45.50 & 39.89 & 5.61 & 2,313 & 4,071 & 0.568 \\
\hline Average & & & -9.16 & & & 7.33 & & & 0.460 \\
\hline
\end{tabular}


Table 6

Comparison of California Voters in Primary and General Elections

\begin{tabular}{|l|c|c|c|c|}
\cline { 2 - 5 } \multicolumn{1}{c|}{} & \multicolumn{2}{c|}{2000} & \multicolumn{2}{c|}{2004} \\
Political Ideology & Primary & General & Primary & General \\
Moderate & 33 & 37 & 40 & 36 \\
Conservative & 42 & 29 & 29 & 26 \\
& & 34 & 31 & 38 \\
Party Affiliation & & & & \\
Registered Democrats & 46 & 48 & 52 & 45 \\
Registered Independents & 9 & 12 & 11 & 15 \\
Registered Republicans & 41 & 36 & 34 & 37 \\
\hline
\end{tabular}

Source: LA Times Exit Polls 


\section{References}

Beckman, James and Jeffery Maiden. 2003. "The Effects of Technology Inclusion on School Bond Electin Success in Oklahoma." Journal of Education Finance 28: $557-576$.

Bowler, Shaun, Stephen P. Nicholson, and Gary M. Sequra. 2006. Earthquakes and Aftershocks: Race, Direct Democracy, and Partisan Change.” American Journal of Political Science 50(1): 146-159.

Christin, Thomas, Simon Hug, and Pascal Sciarini. 2002. "Interests and Information in Referendum Voting: An Analysis of Swiss Voters." European Journal of Political Research 41(6): 759-776.

Donovan, Todd, Caroline J. Tolbert, and Daniel A. Smith. 2008. "Priming Presidential Voters by Direct Democracy.” Journal of Politics 70(4), forthcoming.

Dunne, Stephanie, W. Robert Reed, and James Wilbanks. 1997. "Endogenizing the Median Voter: Public Choice Goes to School.” Public Choice 93(1-2): 99-118.

Ehrenberg, Ronald G., Randy A. Ehrenberg, Christopher L. Smith, and Liang Zheng. 2004. “Why Do School District Budger Referenda Fail?" Education Evaluation and Policy Analysis 26(2): 111-125.

Hajnal, Zoltan L. and Paul G. Lewis. 2003. "Municipal Institutions and Voter Turnout in Local Elections." Urban Affairs Review 38(5): 645-668.

Hasen, Rick. 2007. Will California put GOP over the top? San Diego Union-Tribune, 25 September, Edition F.

Innman, Robert P. 1978. “Test a New “As If” Proposition: Is the Median Voter Really Decisive?" Public Choice 33: 45-65. 
Kousser, Thad, Jeffery Lewis, and Seth Masket. 2007. "Ideological Adaptation? The Survival Instinct of Threatened Legislators." Journal of Politics 69(3): 828-843.

Meredith, Marc and Yuval Salant. 2008. "The Causes and Consequences of Ballot-Order Effects." Stanford University, mimeo.

Moe, Terry M. 2005. "Political Control and the Power of the Agent." Journal of Law, Economics, and Organization 22(1): 1-29.

Nicholson, Stephen P. 2005. Voting the Agenda: Candidates, Elections, and Ballot Propositions. Princeton University Press: Princeton, NJ.

Pequet, Gary M., R. Morris Coats, and Steven T. Yen. 1996. "Special Versus General Elections and Composition of the Voters: Evidence from Louisiana School Tax Elections.” Public Finance Review 24(2). 131-147.

Piele, Philip K. and John Stuart Hall. 1973. Budgets, Bonds, and Ballots. D.C Heath and Company: Lexington, Massachusetts.

Riker, William and Peter Ordenshook. 1968. "A Theory of the Calculus of Voting." American Political Science Review 62, 1968. 25-42.

Romer, Thomas and Howard Rosenthal. 1978. "Political Resource Allocation, Controlled Agendas, and The Status Quo." Public Choice 33: 27-43.

Romer, Thomas and Howard Rosenthal. 1979. "Bureaucrats Versus Voters: On the Political Economy of Resource Allocation by Direct Democracy." Quarterly Journal of Economics 93(4): 563-587.

Romer, Thomas, Howard Rosenthal, and Krishna Ladha. 1984. “If at First You Don't Succeed: Budgeting by a Sequence of Referenda." In H. Hanusch, ed., Public 
Finance and the Quest for Efficiency. Detroit, Wayne State University Press, pp. $87-108$.

Rosenthal, Howard. 1990. “The Setter Model.” In J.M Enelow and M.J Hinich, ed., Advances in the Spatial Theory of Voting. Cambridge, Cambridge University Press, pp. 199-234.

Rubinfeld, Daniel L. 1977. "Voting in a Local School Election: A Micro Analysis." Review of Economics and Statistics 59(1): 30-42.

Rubinfeld, Daniel L. and Randall Thomas. 1980. “On The Economics of Voter Turnout in Local School Elections." Public Choice 35: 315-331.

Smith, Alastair. 2004. Election Timing. Cambridge University Press: New York, NY.

Waters, Dane M. 2003. The Initiative and Referendum Alamanac. Carolina Academic Press: Durham, North Carolina.

Woods, Curtis. 2002. "Voter Turnout in City Elections." Urban Affairs Review 38: 209231. 